\title{
Independence and Impartiality in the ICSID Convention and Arbitration Rules
}

This Chapter analyzes the ICSID Convention's rules and regulations on arbitrators' independence and impartiality, arbitrators' disclosure obligations and the right of the disputing parties to remove unqualified arbitrators. It sheds light on the discussions relating to these provisions during the drafting process of the Convention, and interprets the relevant provisions of the Convention in light of the drafters' regulatory intent.

The focus then shifts from the provisions of the ICSID Convention and Arbitration Rules to the meaning of the notions of independence and impartiality, and the crucial question whether and how the parties' ability to appoint a decision-maker of their choice and the requisite independence and impartiality of this arbitrator can be reconciled.

\section{Legal Framework and Drafting History}

\subsection{The Requirement of Independence and Impartiality}

ICSID arbitrators must be both independent and impartial. The requirement of independence is set forth in Article 14 para. 1 ICSID Convention, which states that arbitrators shall be "persons ... who may be relied upon to exercise independent judgment." ${ }^{46}$ Impartiality, which is usually paired with the obligation of independence, is not explicitly called for in either the English or the French ${ }^{47}$ version of the Convention. The Spanish version of Article 14 para. 1 does however stipulate that arbitrators must be impartial. ${ }^{48}$ Since all language versions of the ICSID Convention are equally authentic, ${ }^{49}$ there is

46 ICSID Convention art. 14, para. 1 states the qualities required of members of the Panels of Conciliators and Arbitrators (ICSID Convention art. 12-16). ICSID Convention art. 40, para. 2 extends these requirements to arbitrators appointed from outside the panels. ICSID Convention art. 14, para. 1 (French version): "Les personnes désignées pour figurer sur les listes doivent ... offrir toute garantie d'indépendance dans l'exercice de leurs fonctions."

48 "Las personas designadas para figurar en las Listas deberán ... inspirar plena confianza en su imparcialidad de juicio."

49 ICSID Arbitration Rule 56. 
general consensus among scholars ${ }^{50}$ and ICSID arbitration users that both requirements are mandatory. The same standard of independence applies to all arbitrators, whether party-appointed or chairpersons. ${ }^{51}$

The early drafts of the Convention, ${ }^{52}$ in particular the Working Paper in the Form of a Draft Convention ${ }^{53}$ and the Preliminary Draft of a Convention on the Settlement of Investment Disputes Between States and Nationals of other States, ${ }^{54}$ did not address arbitrators' independence and impartiality at all. They merely mentioned the other qualities required of arbitrators under Article 14 para. 1 ICSID Convention: high moral character and recognized competence in the fields of law, commerce, industry or finance. ${ }^{55}$ The prerequisite of independence was only inserted towards the end of the drafting process. ${ }^{56}$ Several delegates had voiced the concern that conflicts of interest might arise in the context of a particular dispute, ${ }^{57}$ and highlighted the significance of arbitrators' independence and impartiality for the legitimacy of the system.

A member of the Committee of the Whole on Settlement of Investment Disputes, which was set up to discuss the Working Paper, proposed that a requirement of independence should be added, due to its importance for the

5o Impartiality is also regarded as an implicit requirement for independent judgment. See Rubins and Lauterburg, supra note 32, at 157; SCHREUer ET AL., COMMENTARY, supra note 16, Art. 14, If 5; Markert, supra note 21, at 243.

51 Schreuer et Al., Commentary, supra note 16, Art. 40, I 21; Luttrell, supra note 31, at 219; Markert, supra note 21, at 255; Karel Daele, Challenge and Disqualification of Arbitrators in International Arbitration 9 5-057 (2012). For examples of systems where "non-neutral arbitrators" are accepted, see PAULsson, THE IDEA, supra note 22, at 154-155.

$5^{2}$ For an overview of the background of the drafting history, see Broches, supra note 4 , at 345-348.

53 Working Paper in the Form of a Draft Convention, reprinted in InTERnational Centre for Settlement of Investment Disputes, History of the icsid ConvenTION, Vol. II-1 19-46 (1968) [hereinafter Working Paper].

54 Preliminary Draft of a Convention on the Settlement of Investment Disputes Between States and Nationals of other States, reprinted in ICSID, HistoRY II-1, supra note 53, at 184-235. [hereinafter Preliminary Draft].

55 International Centre for Settlement of Investment Disputes, History of the icsid Convention, Vol. I 72 (1970). See also Schreuer et Al., CommenTARY, supra note 16 , Art. 14, ๆ 2.

56 Draft Convention on the Settlement of Investment Disputes Between States and Nationals of other States, reprinted in ICSID, HISTORY II-1, supra note 53, at 617-618 [hereinafter Draft Convention].

Schreuer et Al., Commentary, supra note 16, Art. 14, ๆ 5 . 
"effectiveness of the new machinery." ${ }^{8}$ His proposal was later supported by most experts at the Consultative Meeting of Legal Experts in Geneva. In particular, the Dutch expert stated that arbitrators should not only be "capable of exercising independent judgment but also of acting with complete impartiality without accepting instructions from the parties appointing them." The Portuguese expert agreed, and added that "an express provision specifying that arbitrators must act with complete independence, would greatly enhance the international prestige and authority of arbitral awards."59

Other legal experts denied the need for such a provision, and questioned its potential scope. The Spanish delegate, for example, asked whether governments would be prevented from appointing their functionaries to the panels, and whether professional relationships between panelists and their appointing State would have to be taken into account. His questions remained unanswered, but the Portuguese expert conceded that independence and impartiality were not abstract and absolute. He insisted, nevertheless, that "persons of recognized standing could be found and relied upon in a given dispute to exercise their functions with complete impartiality in a given case."60

The report on the discussions in the Consultative Meeting of Legal Experts, which summarized the collective conclusions in detail, did not address the opponents' concerns. Instead, it stated that there were no serious substantive disagreements on the qualifications required of arbitrators. ${ }^{61}$ As a consequence, the scope of the requirement of independence and impartiality was not further discussed during the drafting process.

A possible explanation for the lack of attention paid to the delimitation of independence and impartiality in the drafting process is that Article 14 para. 1 ICSID Convention only indirectly applies to arbitrators who are unilaterally or jointly appointed by the parties, from outside the Panel of Arbitrators. ${ }^{62}$

$5^{8}$ See Memorandum of the meeting of the Committee of the Whole (Dec. 18, 1962), reprinted in ICSID, History II-1, supra note 53, at 56 .

59 See Consultative Meeting of Legal Experts (Feb. 17-22, 1964), Summary Record of Proceedings, reprinted in ICSID, History II-1, supra note 53, at 386-388. See also DAELE, supra note $5_{1}$, 9 5 $5^{-027}$.

6o See Consultative Meeting of Legal Experts (Feb. 17-22, 1964), Summary Record of Proceedings, reprinted in ICSID, HISTORY II-1, supra note 53 , at 387-388.

61 Regional Consultative Meetings of Legal Experts on Settlement of Investment Disputes, Chairman's Report on Issues Raised and Suggestions Made with Respect to the Preliminary Draft of a Convention on the Settlement of Investment Disputes Between States and Nationals of Other States (July 9, 1964), reprinted in ICSID, History II-1, supra note 53, at 562 .

62 See supra note 46. 
The delegates' discussions appear to have been focused on the room for maneuver left to States when nominating panel members (who may subsequently be appointed to arbitral tribunals by the Chairman of the ICSID Administrative Council, hereinafter the ICSID Chairman ${ }^{63}$ ). Apart from a mention of the inappropriateness of receiving instructions from an appointing party, references to the relationship between arbitrators and their appointing parties are conspicuously absent from the discussion record, as if the delegates had overlooked the applicability of Article 14 para. 1 ICSID Convention in that setting. Potential conflicts of interest are however much more numerous in the context of party-appointments on an ad hoc basis, and a clear delineation of the scope of independence and impartiality is therefore crucial. The delegates who participated in the drafting process of the ICSID Convention failed to acknowledge this. Quite possibly, they only had a fraction of the potential conflicts of interest in mind when they included the requirement of independence and impartiality in the Convention.

\section{$1.2 \quad$ The Disqualification of Arbitrators}

The procedural enforcement of the requirement of independence and impartiality can occur at two stages. First, a party can request the disqualification of an arbitrator at the appointment stage or during the proceedings. ${ }^{64}$ Second, after the conclusion of the arbitration, a party can commence annulment proceedings. ${ }^{65}$ This second option presupposes that the grounds for the challenge were properly raised during the proceedings leading up to the award, and that the lack of independence or impartiality is serious. ${ }^{66}$ In practice, any sign of partiality constitutes a "serious departure from a fundamental rule of procedure." 67 This study focuses on the first option, namely challenge requests before the conclusion of the proceeding. They are the primary means for

63 The ICSID Chairman is - ex officio - the President of the World Bank. See ICsid Convention art. 5 .

64 ICSid Convention art. 57. See LutTrell, supra note 31, at 220; SChreuer Et AL., ComMENTARY, supra note 16, Art. 14, ๆ 8. Such requests are hereinafter referred to as arbitrator challenges, ICSID challenges, disqualification requests or proposals for disqualification. They initiate disqualification proceedings, which are hereinafter also referred to as removal proceedings or challenge proceedings.

65 ICsid Convention art. 52, para. 1 (d).

66 LUTTRELL, supra note 31 , at 219.

67 Klöckner Industrie-Anlagen $\mathrm{GmbH}$ and others v. United Republic of Cameroon and Société Camerounaise des Engrais, ICSID Case No. ARB/81/2, Decision of the ad hoc Committee, at 119 (May 3, 1985); Schreuer et Al., Commentary, supra note 16, Art. 52, ๆ 294-304. 
parties to enforce their right to independent and impartial decision-makers, while annulment proceedings are a last resort, and therefore subject to stricter requirements.

The prerequisites for a successful disqualification request are set out in Article 57 ICSID Convention:

A party may propose to a ... Tribunal the disqualification of any of its members on account of any fact indicating a manifest lack of the qualities required by paragraph (1) of Article 14.

While the requirement of independence and impartiality under Article 14 para. 1 ICSID Convention is not expressly limited in its scope, the removal of a dependent or biased arbitrator is subject to a manifest lack of these qualities. It is therefore important to determine what precisely qualifies as such a manifest lack, and how this precondition impacts the burden of proof of challenging parties. In order to gain insight on the meaning of the requirement, this book once more turns to the record of the drafting process, and any indication of a specific regulatory intent documented therein.

The requirement of a manifest lack of independence and impartiality was not originally contained in the Convention drafts, and only slipped in later. The Working Paper authorized parties to request the disqualification of an arbitrator "on the ground that he has an interest in the subject matter of the dispute or that he had, prior to his appointment, dealt with the dispute in any capacity whatever."68 The Preliminary Draft removed these limitations, and allowed for disqualification proposals "on account of any fact whether antecedent or subsequent to the constitution of the Commission or Tribunal." ${ }^{\prime 9}$ This unlimited ground for disqualification was criticized in two of the regional Consultative Meetings of Legal Experts. Two delegates desired a more specific provision. ${ }^{70}$

68 Working Paper, supra note 53, art. VII, § 6 (1)-(2).

69 Preliminary Draft, supra note 54, art. v, § 2 (1).

70 See Consultative Meeting of Legal Experts (Feb. 17-22, 1964), Summary Record of Proceedings, reprinted in ICSID, HISTORY II-1, supra note 53, at 436 (intervention of the Turkish delegate, suggesting that the reasons for disqualification should be specifically enumerated); Consultative Meeting of Legal Experts (Apr. 27-May 1, 1964), Summary Record of Proceedings, reprinted in ICSID, HISTORY II-1, supra note 53, at 529 (intervention of the Lebanese delegate, noting that the grounds for disqualification are unclear, enquiring whether a party could challenge the arbitrator appointed by the counter-party, and suggesting a more specific provision, "lest proceedings be protracted indefinitely by successive challenges of arbitrators."). 
The chairman acknowledged that there "seemed to be a strong feeling that the question of the qualifications and the disqualification of ... arbitrators should be dealt with in greater detail," and clarified that the possibility of a "challenge [of the] arbitrator appointed by the other party ... had ... been the principal intent of the provision."71

Based on these comments, the Draft Convention was drawn up. In its Article 6o, it contained a provision on arbitrator disqualification, which was already very similarly worded to today's Article 57. In particular, it included the requirement of a manifest lack of independence and impartiality. ${ }^{72}$ In the subsequent meetings, the provision was not further discussed. Only the German delegation voiced its wish to revert to a more open and general rule, mainly driven by the concern that partiality and dependence should be grounds for disqualification. The chairman clarified that in his opinion, partiality and dependence constituted a lack of the qualities required under Article 14 para. 1 ICSID Convention. ${ }^{73}$ With this statement, the discussions on the issue were closed.

It is striking that the meaning of the manifest lack requirement introduced in the Draft Convention was never discussed by the delegates. Most notably, the chairman's statement, according to which partiality and dependence constitute a lack of the qualities required under Article 14 para. 1 ICSID Convention, fails to answer the pivotal question when such a lack is manifest. The drafting history makes it abundantly clear, however, that the Convention never intended to impose a particularly heavy burden of proof on challenging parties. On the contrary, the general provision on arbitrator challenges was specifically replaced by today's wording in order to provide for the disqualification of biased or dependent arbitrators. While the chairman highlighted that mere allegations without a factual basis would be insufficient as a basis for a successful challenge, ${ }^{74}$ the appropriate threshold for a challenge was

71 Consultative Meeting of Legal Experts (Apr. 27-May 1, 1964), Summary Record of Proceedings, reprinted in ICSID, HISTORY II-1, supra note 53, at 529 .

72 Draft Convention, supra note 56 , at 638 .

73 Memorandum of the Meeting of the Committee of the Whole, February 23, 1965, reprinted in International Centre for Settlement of Investment Disputes, HisTORY OF THE ICSid CONVEntion, Vol. II-2 993 (1986).

74 Summary Proceedings of the Legal Committee Meeting (Nov. 30, 1964), reprinted in ICSID, HIsTORY II-2, supra note 73 , at 728 ("[A] very manifest lack of the qualities enumerated in Article 14 would be necessary for challenging a member of a panel."); Memorandum of the Meeting of the Committee of the Whole (Feb. 16, 1965), reprinted in ICSID, History II-2, supra note 73, at 970 ("[I]t was not enough, however, to allege that the arbitrator 
never specified. In the absence of any reference to the burden of proof imposed on the challenging party, it must be assumed that the manifest lack requirement in Article 57 ICSID Convention does not raise the bar for arbitrator challenges. ${ }^{75}$

As Daele convincingly argues, the qualifying denotation of the term manifest in the context of other provisions of the ICSID Convention ${ }^{76}$ does not apply per analogiam to Article $57 \cdot{ }^{77}$ All other provisions in which the term manifest is used describe exceptional circumstances in which the disputing parties' fundamental rights are constrained. ${ }^{78}$ This is not the case in Article 57 ICSID Convention: Independence and impartiality are not exceptions to the parties' right to freely appoint their decision-makers. On the contrary, the right to an independent and impartial decision-maker itself is a fundamental right, which is procedurally enforced and safeguarded by means of disqualification requests. Accordingly, this remedy should only be limited as far as it is necessary to avoid its abuse and to ensure the effectiveness of arbitral proceedings. ${ }^{79}$ The term manifest must be understood to have a more permissive acceptation in the context of arbitrator challenges pursuant to Article 57 ICSID Convention.

A request for the disqualification of an arbitrator must be made "promptly" in order to be admissible. ${ }^{80}$ According to Article 58 ICsid Convention, disqualification requests are decided on by the unchallenged members of the arbitral

was not of high moral character, but to establish facts indicating a manifest lack of that quality.").

75 See also DAELE, supra note 51, ๆ 5-027.

76 E.g., ICSID Convention art. 36 , para. 3 (requiring that it must be easily recognizable that a request is outside of ICSID's jurisdiction); ICSID Arbitration Rule 41, para. 5 (requiring the lack of legal merit to be established clearly and obviously, with relative ease and dispatch, but conceding that "successive rounds of written and oral submissions" might be necessary, and that "[t]he exercise may ... be complicated, but it should never be difficult."); and ICSID Convention art. 52, para. 1 (b) (requiring an excess of power which is "self-evident, rather than the product of elaborate interpretations one way or another," "plain on its face and not susceptible of argument one way or another," "clear, plain, obvious, evident," so that "it should not take a hundred pages to explain," and "textually obvious and substantially serious," and "quite evident without the need to engage in an elaborate analysis."). See DAE LE, supra note 51, ๆ ๆ 5-028 - 5-030.

77 Id. ๆ

78 Id. $95^{-031 .}$

79 See also Id. ๆ $5^{-0} 3^{2}$.

8o ICSID Arbitration Rule 9. See Kinnear and Nitschke, supra note 13, at 44; SCHREUER ET AL., Commentary, supra note 16, Art. 57, ๆ 11. 
tribunal, in the absence of their challenged colleague..$^{81}$ If they are equally divided, or if the disqualification proposal concerns a sole arbitrator or the majority of arbitrators of a tribunal, the ICSID Chairman decides. The decision on the disqualification of an arbitrator is final. There is no possibility of an appeal. This competence of the unchallenged co-arbitrators to decide on their colleague's disqualification is unusual and subject to doctrinal criticism. The main argument brought forward against this system is that it might incentivize arbitrators to raise the threshold for challenges. ${ }^{82}$

\subsection{Arbitrators' Disclosure Obligation}

In order to enable parties to exercise their right to independent and impartial decision-makers, appointed arbitrators are required to share certain information about their personal and professional background with them. Not only "past and present professional, business and other relationships (if any) with the parties," but "any other circumstance that might cause [their] reliability for independent judgment to be questioned by a party" are covered by the disclosure obligation..$^{83}$ In this context, the relevant threshold is whether a particular circumstance is likely to give rise to justifiable doubts as to an arbitrator's independence and impartiality. ${ }^{84}$

Scholars have repeatedly highlighted that this threshold does not impact the burden of proof required for arbitrator challenges. ICsID Arbitration Rule

81 ICSid Arbitration Rule 9, para. 4. See Schreuer et Al., Commentary, supra note 16, Art. 58 .

82 Markert, supra note 21, at 248-250 (including further references); Fry and Stampalija, supra note 31, at 257-258; Krista Nadakavukaren Schefer, Judicial ethics in international economic law: what standards of independence and impartiality apply to arbitrators and panelists?, in Establishing Judicial Authority in International Economic LAW 215, 233 (Joanna Jemielniak, Laura Nielsen, \& Henrik Palmer Olsen eds., 2016) ("In the small world of international arbitrators, disqualifying a fellow arbitrator on 'mere appearances' may not be well-regarded.").

83 ICSID Arbitration Rule 6, para. 2.

84 International Centre for Settlement of Investment Disputes, Suggested Changes to the icsid Rules and Regulations, Working Paper of the ICSID SECRETARIAT 12 (May 12, 2005), available at https://icsid.worldbank.org/apps/ ICSIDWEB/resources/Documents/Suggested\%2oChanges\%2oto\%2othe\%2oICSID\%20 Rules\%2oand\%2oRegulations.pdf; Schreuer et AL., Commentary, supra note 16, Art. 40, ๆף 19-20; LutTRELL, supra note 31, at 222; Rubins and Lauterburg, supra note 32, at 160; Reed, Paulsson, AND Blackaby, supra note 13, at 133; Sheppard, supra note 32 , at 155 (outlining the ICSID Secretariat's proposal to amend Arbitration Rule 6, para. 2, so as to explicitly require justifiable doubts, consistently with other arbitration rules). 
6 para. 2 has a different regulatory purpose from Article 57 ICSID Convention: It aims at avoiding bias rather than eliminating biased arbitrators, and is therefore designed to be more comprehensive. ${ }^{85}$ Out of numerous disclosures, only very few will give rise to a challenge.

The failure to disclose relevant circumstances has repeatedly served as a basis for disqualification requests. Its sufficiency as a prima facie basis for disqualification has however consistently been denied in decisions on ICSID arbitrator challenges. ${ }^{86}$ Chapter 2 therefore focuses on invoked disqualification grounds other than the breach of the disclosure obligation.

2

\section{Delimiting Independence and Impartiality in a System of Party-appointments}

\subsection{The Notions of Independence and Impartiality}

The ICSID Convention neither defines nor delimits the concepts of independence and impartiality. While the definition of these notions remains difficult, ${ }^{87}$ most scholars agree on the following characteristics of independence and impartiality:

Independence is generally defined as the absence of an actual, identifiable relationship with one of the disputing parties, or with someone closely connected to a party. ${ }^{88}$ The mere existence of such a connection calls the adjudicator's independence into question, irrespective of the effect the relationship has on the arbitrator. Where the arbitrator is familiar with counsel for one of the disputing parties, the question is more difficult. Such relationships are only contrary to the requirement of independence if they exceed a certain de minimis threshold, for example if an arbitrator's financial tie to a counsel is significant or if a social relationship goes beyond a remote acquaintance or sporadic encounters. ${ }^{89}$ The point at which an insignificant connection

85 Rogers, Arbitrator Ethics, supra note 24, at 638; Fatima-Zahra Slaoui, The Rising Issue of “Repeat Arbitrators": A Call for Clarification, 25 ARB. INT'L. 103, 118 (2009).

86 See Kinnear and Nitschke, supra note 13, at 41.

87 Rubins and Lauterburg, supra note 32, at 153; Kee, supra note 22, at 181 ("Independence and Impartiality [sic] are two very important words for international arbitration. Yet for all their importance they are two words whose precise meanings are frequently shrouded in mystery and surrounded by controversy."); Eric A. Schwartz \& Yves Derains, Guide to the icc Rules of Arbitration 115 (2nd ed. 2005).

88 Kee, supra note 22, at 183; Markert, supra note 21, at 243; Rubins and Lauterburg, supra note 32 , at 155; Tupman, supra note 43, at 29; Reinisch and Knahr, supra note 24, at 106.

89 Kee, supra note 22 , at $183^{-184}$. 
becomes significant is not defined in abstract terms. Because an arbitrator's independence is assessed purely on the basis of the existence of a connection to a party or counsel, it is said to be an objective criterion. Whether the arbitrator (or the appointing party) believes to be capable of independently and fairly forming an opinion, despite the connection, is irrelevant. ${ }^{90}$

Impartiality, on the other hand, calls for the absence of a subjective, internal predisposition towards one of the parties and their argument. ${ }^{91}$ This assessment is more abstract and difficult to quantify, since it concerns the arbitrator's state of mind ${ }^{92}$ Thus, the burden of proof for a challenge based on partiality is usually reduced. Under most arbitration rules (as in most other dispute resolution systems), the appearance of bias or justifiable doubts as to the arbitrator's impartiality are sufficient for a disqualification..$^{93}$

As logical and intuitive as the portrayal of independence and impartiality as dualistic concepts (objective and subjective) ${ }^{94}$ appears, it is inevitably simplistic. On the one hand, not all connections to a party impair an arbitrator's independence, and justify a disqualification..$^{95}$ The relevance of

90 Schreuer et Al., Commentary, supra note 16, Art. 40, I 21 (considering the arbitrator's general moral character to be equally unsubstantial); Rubins and Lauterburg, supra note 32, at 155; Nigel Blackaby et AL., RedFERn AND HUNTER on INTERNATIONAL Arbitration 94.77 (6th ed. 2015); Schwartz ANd Derains, supra note 87, at 117 .

91 Kinnear and Nitschke, supra note 13, at 50-51; David D. Caron \& LeE M. Caplan, The uncitral Arbitration Rules 213 (2nd ed. 2013); Markert, supra note 21, at 243; Kee, supra note 22, at 184; BLACKABY ET AL., supra note 9o, ๆ 4.78; Tupman, supra note 43, at 29; Reinisch and Knahr, supra note 24, at 106.

92 Kee, supra note 22, at 184; BLACKABY ET AL., supra note 9o, I 4.78; Rubins and Lauterburg, supra note 32, at 155; SCHWARTZ AND DERAINS, supra note 87, at 117.

93 Kee, supra note 22, at 184; BLACKABY ET AL., supra note 90, ๆ 4.78; SCHWARTZ AND DeRAINS, supra note 87 , at 117 .

94 See also Kinnear and Nitschke, supra note 13, at 5o; CARON AND CAPLAN, supra note 91, at 213 (applying a different terminology by distinguishing independence as the freedom from external control, and impartiality as the absence of internal predispositions. Substantively, the connotation of these terms is synonymous with the differentiation between objective and subjective concepts.).

95 Schwartz ANd Derains, supra note 87, at 119 ("[T]he essential feature of independence [is] the absence of a 'close, substantial, recent and proven relationship' between a party and a prospective arbitrator. How close is 'close', how substantial is 'substantial' and how recent is 'recent', however .... Thus, no matter how much more objective the notion of 'independence' may be than that of 'impartiality', 'independence' nonetheless remains

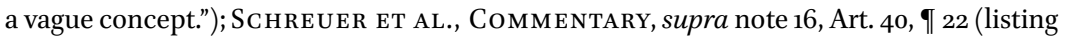
the kinds of relationships which might affect an arbitrator's independence); Kee, supra note 22, at 183 (referring to "offending relationships."). 
any given relationship depends on how likely it is to affect the arbitrator's free decision-making. Thus, assumptions regarding the arbitrator's state of mind - subjective, internal criteria - complement the otherwise objective evaluation. ${ }^{96}$ On the other hand, challenges based on an arbitrator's alleged lack of impartiality are generally required to be tied to a factual (objective) basis. ${ }^{97}$ As a consequence, the concepts of independence and impartiality are both somewhat subjective, and therefore vague. The advantage of this vagueness is that it allows for the circumstances of a particular case to be taken into consideration. Its disadvantage is that in the absence of a clarification of the abstract terms of independence and impartiality, the practical meaning of those notions (and the outcome of disqualification requests) is unpredictable. ${ }^{98}$

In practice, distinctions between independence and impartiality are often overlooked, and the terms are used interchangeably.99 This considerably complicates the interpretation of challenge decisions. Terminologically distinguishing the terms, however, is less important and conducive to determining the scope of the concepts, than defining their common purpose. Looking beyond linguistic and conceptual differences, the notions of independence and impartiality are complimentary, and pursue the same goal: At their core, independence and impartiality aim to ensure parties' equality of arms, fair trial and procedural justice ${ }^{100}$ - factors which are crucial for the perceived legitimacy of the ICSID system. ${ }^{101}$ In more concrete terms, independence and impartiality

96 Horacio A. Grigera Naón, Factors to Consider in Choosing an Efficient Arbitrator, in ICCA Congress Series No. 9: Improving the Efficiency of Arbitration Agreements and Awards. 40 Years of Application of the New York Convention, 286, 288 (Albert Jan van den Berg ed., 1999) ("[T]he objectiveness of the independence test should not be exaggerated.... [T] he test [requires] an evaluation of ... 'closeness' ... and cannot then be exclusively objective. It [is] permeated with subjective value judgments highly influenced by the cultural and legal background [of] those applying the independence test.").

97 Kee, supra note 22, at 184 .

98 Catherine A. Rogers, Ethics in International Arbitration 1 ף 6.69-6.74 (2014).

99 Kee, supra note 22, at 183; Rogers, Етнics, supra note 98, ๆ 2.53 ("To the extent some logical or linguistic distinction can be made, however, in practical terms it appears to be largely a distinction without a difference. These terms are used more or less interchangeably by institutions and courts, and their true meaning is determined more in their application than in their phraseology."); Tupman, supra note 43, at 29.

100 Nadakavukaren Schefer, supra note 82, at 217-218.

101 Franck, FaIRness, supra note 23, at 7 ("To be effective, the system must be seen to be effective. To be seen as effective, its decisions must be arrived at discursively in accordance 
guarantee the arbitrator's capacity to evaluate the merits of each case openmindedly, rationally, and objectively, without relying on extraneous factors. ${ }^{102}$ It is precisely this ability that should guide parties' appointments, arbitrators' decisions whether to accept specific appointments, as well as the adjudication of disqualification requests.

\subsection{Party-appointments and Independence and Impartiality}

Arbitrator independence and impartiality is often described in broad and farreaching terms, because it is "framed in reference to concepts of judicial [independence and] impartiality."103 In light of the adjudicatory function performed by arbitrators, the analogy appeals to intuition: If it were not for the parties' arbitration agreement, the same disputes would be settled by judges. Besides this obvious functional similarity, however, there are also fundamental differences between arbitrators and judges, which justify a more differentiated approach to the obligation of independence and impartiality.

The most important difference between judges and arbitrators is that judges are institutionally insulated from the parties, and are assigned cases on a more or less random basis. The judicial office is designed for contacts between decision-makers and litigants (as well as decision-makers and the subjectmatter of a case) to be avoided. In the rare event in which such a connection does exist, it is an unusual and coincidental anomaly, which justifies a judge's recusal from the specific case. ${ }^{104}$ Arbitrators, on the other hand, are characteristically appointed by the parties, on an ad hoc basis, for the resolution of

with what is accepted by the parties as right process."); Caron, Investor State Arbitration, supra note 23, at 514; PAULsSON, THE IDEA, supra note 22, at 17; Franck, Integrating Investment Treaty Conflict, supra note 22, at 214-215; Kee, supra note 22, at 195.

Kinnear and Nitschke, supra note 13, at $5_{1}^{1}$ (" $[\mathrm{T}]$ hese requirements ensure that an arbitrator has 'the ability to consider and evaluate the merits of each case without relying on factors that have no relation to such merits."); GARY B. Born, InTERnAtional ARbitration: LAW ANd Practice 129 (2012) (“[I]ndependence and impartiality ... are fundamental to the arbitral process, which is an adjudicatory procedure requiring a neutral and objective tribunal."); Sobota, supra note 27, at 311 ("If parties want to appoint their own arbitrator, they also want the other side's arbitrator to be open to reason."); Richard Woolley, Is arbitrator impartiality a myth?, Global Arbitration Review (June 9, 2015), http://globalarbitrationreview.com/news/article/33,866/ (quoting Mark Beckett highlighting that impartiality requires the arbitrator to have an open mind, not to be a blank slate).

103 Rogers, Arbitrator Ethics, supra note 24, at 631.

104 Id. at 633-634. 
a specific dispute. It is not their exclusive (and often not even their main) occupation to serve as arbitrators. ${ }^{105}$

The tension between party-appointments and the idea of independence and impartiality as it derives from the judicial context is apparent:106 If the parties' ability to participate in the setup of the decision-making body is to be meaningful at all, they must be able to select a suitable arbitrator, based on this person's qualifications. This logically presupposes some degree of familiarity between the nominee and the appointing party, or counsel for the party - be it based on the candidate's academic publications on particular legal questions, or in virtue of the expertise the person has acquired as a counsel or arbitrator in a particular field. ${ }^{107}$ The best guarantee for the arbitrator's competence is the party's prior professional experience with the person. None of the described bases for an appointing party's selection would hold up to scrutiny based on judicial standards of independence. The European Court of Human Rights, for example, views independence as a function of the manner of the decision-maker's appointment, the term of office, the guarantees against outside pressures, and the appearance of independence generated by these factors. ${ }^{108}$ This precludes pre-existing connections between the decision-maker and the disputing parties. Not only unilaterally designated, but also jointly appointed arbitrators would therefore generally fail to fulfill judicial standards of independence.

105 Luttrell, supra note 31, at 239; Thomas J. Stipanowich \& ZaChary P Ulrich, Arbitration in Evolution: Current Practices and Perspectives of Experienced Commercial Arbitrators 19-23 (2014) (providing empirical data on the work time utilization of commercial arbitrators).

106 Yuval Shany, Squaring the Circle? Independence and Impartiality of Party-Appointed Adjudicators in International Legal Proceedings, 30 Loy. L.A. InT'L. \& ComP. L. REv. 473, 488 (2008); DAE LE, supra note 51, \ 6-191; Kee, supra note 22, at 182 and 193; Rogers, Arbitrator Ethics, supra note 24, at 632; Axel H. Baum, Editorial: Maintaining the Essence of Arbitration, 4 J. INT'L. ARB. 4, 5 (1987) ('An arbitrator, as opposed to a professional judge, by the nature of his background is more vulnerable to criticism or challenge."). Contra Rubins and Lauterburg, supra note 32 , at 153 .

107 See Markert, supra note 21, at 255; LUtTRELL, supra note 31, at 226; SCHREUER ET AL., Commentary, supra note 16, Art. 57, If 22; Rachel Bendayan, Interview with a Leading International Arbitrator: L Yves Fortier, 18 IBA ARB. News 18, 20 (2013) ("The expertise of the lawyers appointed as arbitrators as opposed, in general, to the pot-luck selection of national judges is another distinct advantage of arbitration over litigation.").

108 Rubins and Lauterburg, supra note 32, at 155 (referencing Findlay v. United Kingdom, ECHR 22,107/93 (Feb. 25, 1997), para. 73). See also Tom Dannenbaum, Nationality and the International Judge: The Nationalist Presumption Governing the International Judiciary and Why it Must Be Reversed, 45 Cornell InT'L. L.J. 77, 111-112 (2012). 
Three conclusions could be drawn from the described situation: First, that party-appointments are incompatible with the fundamental principle of independence and impartiality and should therefore be abolished. Second, that parties who have entered into an arbitration agreement have waived their right to an independent and impartial decision-maker (at least to some extent), in favor of their right to freely appoint their decision-maker. Or, third, that the tension between independence and impartiality and partyappointments requires a differentiated approach, rather than a radical solution. Namely, that arbitrators' independence and impartiality should be clearly delimited, so as to facilitate the benign and legitimate interests pursued by the system of party-appointments, while effectively preventing dependence and bias.

The abolishment of party-appointments by virtue of their incompatibility with independence and impartiality has been advocated by various distinguished scholars, and is analyzed below, in Chapter 4, Part 1.

The second conclusion mentioned above is refuted by the provision for arbitrators' independence and impartiality in Article 14 para. 1 ICSID Convention, and in all major arbitration rules. ${ }^{109}$ The drafting history of the ICSID Convention illustrates that ensuring the independence and impartiality of the decision-makers was a priority for the delegates. ${ }^{110}$ Nowhere in the drafting record have they expressed the intention to cut back on independence and impartiality, in order to allow parties to freely appoint their decision-makers. On the contrary, Article 40 para. 2 ICSID Convention has been conceived to limit the parties' choice, and is an expression of the precedence given to the parties' right to an independent and impartial decision-maker. ${ }^{111}$

109 United Nations Commission on International Trade Law Rules on Transparency in Treaty -based Investor-State Arbitration and Arbitration Rules, art. 11, G.A. Res. 68/109, U.N. Doc. A/RES/68/109 (Dec. 16, 2013) [hereinafter uncitral Arbitration Rules (2013)]; Arbitration Rules of the Arbitration Institute of the Stockholm Chamber of Commerce, art. 14, para. 1 [hereinafter scc Arbitration Rules]; Rules of Arbitration of the International Chamber of Commerce, art. 11, para. 1 [hereinafter ICc Arbitration Rules].

110 See supra Part 1.1.

111 See also DAELE, supra note 51, ๆ 5-111 (stating, at first, that "[ $\mathrm{t}]$ he right to appoint an arbitrator ... is indeed qualified by the requirement that the entire Tribunal is independent and impartial," but clarifying in the subsequent section that the Convention and Rules "provide that each of the arbitrators shall be independent and impartial."); SCHreuer Et Al., Commentary, supra note 16, Art. 37, \ 2 (listing the requirement of arbitral independence and impartiality pursuant to ICSID Convention art. 40, para. 2 as a limit to the parties' freedom of choice in the constitution of tribunals). 
This prioritization is also expressed in Article 39 ICSID Convention, which provides that " $[\mathrm{t}]$ he majority of the arbitrators shall be nationals of States other than the Contracting State party to the dispute and the Contracting State whose national is a party to the dispute." The drafting history of this provision reveals that the appointment of national arbitrators was restricted in order to avoid a situation where the chairperson would be the only independent and impartial decision-maker on the tribunal. ${ }^{112}$ Clearly, the delegates did not believe, as is now often argued, ${ }^{113}$ that the independence and impartiality of one arbitrator could balance out potential dependencies or preconceptions of the other two. On the contrary, they highlighted the importance of the independence and impartiality of all arbitrators, including the ones unilaterally appointed by the parties. Otherwise, the president of the tribunal would have no other choice than to side with one of the partisan arbitrators, in order to achieve a majority. ${ }^{114}$ Although Article 39 ICSID Convention concerns the nationality of the arbitrators, this reasoning also applies to their independence and impartiality. It confirms that the provision for the independence and impartiality of all arbitrators, regardless of their appointing party, is not a mere platitude, but a serious guarantee, based on valid interests.

By submitting to arbitration under the ICSID Convention, parties subscribe to this prioritization. ${ }^{115}$ Thus, their ability to appoint the decision-makers is limited by the requirement of independence and impartiality, and not the other way around. It is not an option to "acknowledge ... an appearance of partiality ... but [to] let it pass on the assumption that this is what the parties have chosen."116 The repercussions of awards in investor-State arbitration

112 Schreuer et Al., Commentary, supra note 16, Art. 39, 92.

113 Franck, The Role of International Arbitrators, supra note 24, at 12; Alexis Mourre, Are Unilateral Appointments Defensible? On Jan Paulsson's Moral Hazard in International Arbitration, Kluwer Arbitration Blog (Oct. 5, 2010), http://kluwerarbitrationblog.com/2010/10/05/are-unilateral-appointments-defensible-on-jan-paulssons-moral -hazard-in-international-arbitration/ (explaining that party-appointed arbitrators sometimes defend their appointing parties' interests with such fervor that a strong chairperson will ignore them, and draft an award without paying attention to their tactics).

114 Schreuer et Al., Commentary, supra note 16, Art. 39, 97.

115 Paulsson, The IdeA, supra note 22, at 17 (arguing that the parties assign decisionmaking authority to three arbitrators, and therefore expect all three to be impartial, but conceding that this is at least the case ex ante, for as the proceedings evolve, parties might lose sight of the goal of resolving a dispute, and "most of all care about winning."); Franck, The Role of International Arbitrators, supra note 24, at 5-6.

116 Sobota, supra note 27 , at $310-311$. 
are often not only borne by the disputing parties, but also by the citizens of the Respondent State. Accordingly, disputing parties must not be allowed to waive their right to independent and impartial decision-makers, and to consent to a certain degree of dependence or bias. The procedural integrity of the decision-making process is of utmost importance for the legitimacy of individual decisions, ${ }^{117}$ as well as the institution as a whole. This precludes the possibility of such waivers.

Last but not least, the third proposition set out above is the one supported by this author. Namely, there is not an incompatibility, but merely a tension between independence and impartiality on the one hand, and partyappointments on the other hand. This tension calls for a clear delimitation of independence and impartiality in the context of ICSID arbitration, tailored to the function of its arbitrators, and in variance with the judicial standard of independence and impartiality. ${ }^{118}$ The benign and legitimate interests pursued by the system of party-appointments should not be hindered, but situations in which the familiarity with a participant (a party or a counsel) or with the subject-matter of the proceeding would inhibit the arbitrator's capacity to evaluate the merits of the case open-mindedly, rationally, and objectively, without relying on extraneous factors, must be prevented.

Party-appointments pursue a legitimate goal to the extent they ensure the parties' buy-in into a system which would otherwise be fraught with uncertainties and unpredictability. ${ }^{119}$ In the eyes of the parties, their control over the appointment of the decision-makers attenuates the uncertainty caused by the arbitrators' high degree of discretion (mainly due to the absence of a rule of binding precedent, and the lack of an appeals mechanism), and their varied ideological, political, and national backgrounds. ${ }^{120}$ It improves the palatability

117 Paulsson, The IdeA, supra note 22, at 147.

118 Shany, supra note 106, at 488; DAELE, supra note 51, \ 6-191; Kee, supra note 22, at 182 and 193; Rogers, Arbitrator Ethics, supra note 24, at 632. Contra Rubins and Lauterburg, supra note 32 , at 153 .

119 Eric A. Posner \& John C. Yoo, A Theory of International Adjudication uC Berkeley Public Law Research Paper No. 1466 (2004); Eric A. Posner \& John C. Yoo, Judicial Independence in International Tribunals, 93 CALIF. L. Rev. 1, 7 (2005) [hereinafter Posner and Yoo, Judicial Independence]; Rogers, Eтнics, supra note 98, I 2.39; Park, Arbitration's Discontents, supra note 24, at 593.

120 See Franck, Structure, supra note 41, at 247-248; Park, Arbitration's Discontents, supra note 24, at 593. See also Adam M. Smith, "Judicial Nationalism" in International Law: National Identity and Judicial Autonomy at the ICJ, 40 TEx. INT'L. L.J. 197, 203 (2005) (stating, in the context of ICJ ad hoc judges, that they are permitted to participate in the decisionmaking "[b]ecause States ...would have it no other way."). 
of awards, since parties are assured that their arguments were heard ${ }^{121}$ and that the decision was made by a competent and qualified body. ${ }^{122}$

The parties' desire for such control manifests itself in several dispute resolution mechanisms: Article 12 para. 5 ICC Arbitration Rules provides for the appointment of the chairperson of the arbitral tribunal by the ICC Court, unless the parties agree upon another procedure. The parties, however, derogate from this default mechanism in almost sixty percent of all cases, ${ }^{123}$ and agree on a chairperson, or have the party-appointed arbitrators agree on one. The Arbitration Rules of the London Court of International Arbitration (LCIA) ${ }^{124}$ provide for the institutional appointment of all arbitrators, unless the parties agree to nominate them. ${ }^{125}$ Despite the flawless reputation of the LCIA for arbitrator appointments, parties depart from this default rule in over fifty percent of all cases. ${ }^{126}$ The China International Economic and Trade Arbitration Commission Hong Kong Arbitration Center (CIETAC) is also moving away from its roster system, and towards unrestricted party-appointments, in order to "accommodate the expectations of foreign parties." ${ }^{27}$ In the International Court

121 Franck, The Role of International Arbitrators, supra note 24, at 12 (highlighting that such a better understanding of the parties must not necessarily turn into bias, and does not predispose the outcome of the proceeding).

122 See Charles N. Brower \& Charles B. Rosenberg, The Death of the Two-Headed Nightingale: Why the Paulsson - Van Den Berg Presumption That Party-Appointed Arbitrators are Untrustworthy is Wrong-Headed, 29 ARB. INT'L. 7, 25 (2013) ("Parties may find it difficult to complain if they themselves had an active role in the constitution of the tribunal."); Mourre, supra note 113. In the context of national judges in international adjudication, see Smith, supra note 120, at 231 ("keep[ing] nationality as a factor in judicial nominations ... provides some psychic 'ownership' to states in the ICJ process and can potentially promote compliance with Court decisions."); Stephen M. Schwebel, National Judges and Judges Ad Hoc of the International Court of Justice, 48 InT'L. CoMP. L.Q. 889, 891-892 (1999) [hereinafter Schwebel, National Judges]; Il Ro Suh, Voting Behavior of National Judges in International Courts, 63 AM. J. INT'L. L. 224, 234 (1969); Dannenbaum, supra note 108, at 114 and 169; Park, Arbitration's Discontents, supra note 24, at 593.

123 Mourre, supra note 113.

124 Arbitration Rules of the London Court of International Arbitration [hereinafter LCIA Arbitration Rules].

125 LCIA Arbitration Rules art. 5.6, 5.7 and 7 (providing for a similar mechanism as under the ICC Arbitration Rules).

126 Mourre, supra note 113.

127 Ank A. Santens, The Move Away from Closed-List Arbitrator Appointments: Happy Ending or a Trend to Be Reversed?, Kluwer Arbitration Blog (June 28, 2011), http:// kluwerarbitrationblog.com/2011/o6/28/the-move-away-from-closed-list-arbitrator -appointments-happy-ending-or-a-trend-to-be-reversed/ [hereinafter Santens, Move Away]. 
of Justice (ICJ), parties who do not have a national on the court may appoint an ad hoc judge when they are involved in a case. ${ }^{28}$ Last but not least, in the ICSID system, parties apparently "go to great lengths to avoid ICSID making the appointment of the chair from its roster"129 - approximately seventy-one percent of all arbitrator appointments are made by the parties alone, without any assistance from ICSID. ${ }^{130}$

Posner and Yoo even go so far as to consider the parties' control over the appointment of the decision-makers the main driver of an international dispute resolution mechanism's legitimacy. Not independence creates legitimacy in international dispute settings, they argue, ${ }^{131}$ but the parties' control over the composition of the decision-making body, which ensures the parties' confidence in the relative predictability of the proceeding. Without partyappointments, the respective dispute resolution mechanisms would fall into desuetude, and would thus forfeit their legitimacy. ${ }^{132}$

It is the view of this author that the proposition of Posner and Yoo goes too far. The parties' control over the decision-makers, taken to its extreme, does not foster the parties' confidence and trust: As soon as the counterparty

128 Statute of the International Court of Justice art. 31, para. 2-3, June 26, 1945, I.C.J. Acts \& Docs. 59 [hereinafter ICJ-Statute]. See Suh, supra note 122, at 236 ("However appealing the theoretical objections raised against the system of national judges may seem, to abolish it would probably be impossible, since States still attach much importance to having one of their subjects on the bench when they appear before a court of justice."); Pieter Hendrik Kooijmans, Article 31, in The Statute of the International Court of Justice: A Commentary 530, ๆ 2 (Andreas Zimmermann et al. eds., 2nd ed. 2012) (“[G]iving both parties the right to have a judge of their nationality on the bench could be instrumental in overcoming the traditional mistrust of States towards a permanent judicial body, in particular, since the future of such a body would depend ultimately on the willingness of individual States to utilize it for the settlement of their disputes.").

129 Caron, Investor State Arbitration, supra note 23, at 519.

130 Kinnear and Nitschke, supra note 13, at 39.

131 Posner and Yoo, Judicial Independence, supra note 119, at 12-13 ("International law scholars have transferred the logic of independence from the domestic arena to the international sphere.... [T] he conventional wisdom overlooks the profound differences between the settings in which domestic and international courts operate.").

132 Id. at 73. But see Douglas Earl McLaren, Party-Appointed vs List-Appointed Arbitrators: A Comparison, in Towards a Science of International Arbitration: ColLected Empirical Research 161, 163 (Christopher R. Drahozal \& Richard W. Naimark eds., 2005) (suggesting, based on a survey on user preferences for party-appointed or list-appointed arbitrators, that "the perceived difference between the party-appointed and list-appointed methods of arbitrator selection may not be as stark ... as previously imagined."). 
visibly exercises more control over the arbitrator it has appointed, the ideal of control transforms into a perception of bias, and confidence turns into distrust towards a system which condones partiality. ${ }^{133}$ After all, "the corollary of being able to pick your own arbitrator is that so can the guy on the other side." ${ }^{134}$ Thus, as has been set out above, independence and impartiality must have priority over and delimit the parties' autonomy to appoint their decision-makers.

The definition of independence and impartiality in the context of ICSID arbitration must strike a careful balance. It must be tailored to the system's functions, without unnecessarily constraining party-appointments. ${ }^{135}$ This balance should be determined by the purpose of the guarantee of independence and impartiality, as identified above: The arbitrator's capacity to evaluate the merits of each case open-mindedly, rationally, and objectively, without relying on extraneous factors.

133 See Paulsson, The Idea, supra note 22, at 162.

134 See David Samuels, Rees's rules for complex disputes, Global Arbitration Review (July 7, 2011), http://www.globalarbitrationreview.com/news/article/29,614/reess-rules-complex -disputes/.

135 See also Rogers, Eтнics, supra note 98, ๆ 8.10 ("Ethical regulation of adjudicator impartiality ... is not about prohibiting all forms of partiality or bias. It is instead about selecting what types of partiality or bias are appropriate to the particular system and devising structures and procedures that harness those biases and prevent other undesirable ones."), ๆ 7.30 (highlighting that different dispute resolution designs serve different goals and communities, and therefore entail a different prioritization of ethical obligations: "In crafting these different adjudicatory models, architects of various systems calibrate differently the specific roles assigned to adjudicators in relation to parties and advocates, and as a consequence, adjudicators' professional ethical obligations in these systems differ."). 